\title{
Macroeconomic Variables, Volatility and Stock Market Returns: A Case of Nairobi Securities Exchange, Kenya
}

\author{
Evans Kirui ${ }^{1}$, Nelson H. W. Wawire ${ }^{2} \&$ Perez O. Onono ${ }^{3}$ \\ ${ }^{1}$ School of Economics, Kenyatta University, Kenya \\ ${ }^{2}$ Dean School of Economics, Kenyatta University, Kenya \\ ${ }^{3}$ Chairperson of the Applied Economics Department, Kenyatta University, Kenya \\ Correspondence: Evans Kirui, School of Economics, Kenyatta University, Kenya. E-mail: \\ kirui.evanskirui@gmail.com
}

Received: February 25, 2014

Accepted: May 19, 2014

Online Published: July 25, 2014

doi:10.5539/ijef.v6n8p214

URL: http://dx.doi.org/10.5539/ijef.v6n8p214

\begin{abstract}
This study sought to evaluate the relationship between Gross Domestic Product, Treasury bill rate, exchange rate, inflation and stock market return in Nairobi Securities Exchange Limited. The study determined the response of the stock returns to a shock in each of the macroeconomic variables. The effect of changes in each of the macroeconomic variable on the volatility of stock returns in Nairobi Securities exchange limited was also determined. Engle-Granger two step method was used to establish the co integrating relationship between stock returns and the macroeconomic variables. Threshold Genaralized Autoregressive Conditional Heteroscedasticity (TGARCH) model was used to capture the leverage effects and volatility persistence at the NSE. Published time series quarterly data from 2000 to 2012 was sourced from the Central Bank of Kenya, Kenya National Bureau of Statistics. Empirical results of the regression model revealed that exchange rate showed a significant relationship with stock returns. For a one percentage increase in depreciation of a domestic currency, the model predicted stock returns to decrease by 1.4 percent. Gross Domestic Product, Inflation and the Treasury bill rate indicated insignificant relationships. The effects of one standard deviation shock on each of the macroeconomic variable on stock returns revealed that shock in exchange rate was negative but eventually reverted back to equilibrium thereafter. The results of the TGARCH model for exchange rate, Gross Domestic Product and Treasury bill rate revealed that the impact of news was asymmetric and there was presence of leverage effects. There was absence of volatility persistence among all the macroeconomic variables.
\end{abstract}

Keywords: leverage effect, macroeconomic variables, share index, stock market returns, volatility

\section{Introduction}

\subsection{Background of the Study}

Stock market is a market that deals with the exchange of securities issued by publicly quoted companies and the government. The market is a crucial institution in an economy which greatly determines and indicates the performance of an economy. The nature and the state of a stock market is of great concern to the government, investors and generally all the stake holders. As an economic institution, stock market plays a major role of enhancing the efficiency of capital formation and allocation. Thus the overall development of the economy is a function of how well the stock market performs. Empirical evidence has shown that the development of a capital market is essential for economic growth (Ashaolu \& Ogunmuyiwa, 2010).

Stock prices, hence stock returns are generally believed to be determined by some fundamental macroeconomic variables such as interest rates, money supply, inflation, exchange rate, and Gross domestic Product. Changes in stock prices are linked with macroeconomic behavior in advanced countries (Muradoglu et al., 2000). Ross (1976) employed statistical tools like in the Arbitrage Pricing Theory (APT) and initiated the use of variables without the need of pre specification of variables in determination of stock returns. This did not take too long before it was criticized. Chen, Roll and Ross (1986) were the first to employ specific macroeconomic factors as proxies for undefined variables in the APT. The study attempted to express the equity returns as a function of macroeconomic variables. Since economic forces like interest rates, Treasury bill rates, influenced expected dividends and the discount rate, it was concluded that stock prices hence stock returns are systematically affected 
by economic variables (Elly \& Oriwo, 2013).

Most of the African economies are fragile and resilient to both internal and external shocks hence macroeconomic factors are more likely to influence African investments returns. The relationship between macroeconomic variables and stock returns has emerged due to the fact that the Capital asset Pricing Model (CAPM) assumes that the uncertainty about future prices of securities is the only risk that the investors are concerned with (Sharpe, 1964). However, investors are also concerned about other risks that affect their investment opportunities and investment returns. For example, the uncertainty about macroeconomic variables such as Gross Domestic Product, inflation, exchange rates, money supply, and interest rates, are other risks other than the market risks.

The gradual abolition of foreign exchange control in 1980s and 1990s in the emerging economies, Kenya included, has created an avenue for international investment and portfolio diversification. This saw the government of Kenya, in 1989 expanding the scope of foreign investment by introducing incentives for capital market growth. They include the setting up of tax free venture capital fund, licensing of dealing firms to improve liquidity, allowance of beneficial ownership by foreigners in local brokers firms, and removal of capital gains tax on insurance company's investment (Mutai, 2005).

Since Kenya is one of the emerging economies in Africa, its stock market performance is highly dependent on the nature of the macroeconomic variables. These variables are considered to be causes of stock return volatility existing in NSE and may lead to stock market crisis (Odhiambo, 2012). According to the International Finance Corporation (IFC), all markets in the developing countries are treated as emerging. Kenya's capital market, the Nairobi securities Exchange Limited (NSE) is thus one of the emerging markets of the world. The market is characterized by; low trading volume, low turnover ratios, few listed companies, and inefficient information delivery (Nairobi Stock Exchange, 1997).

The relationship between stock prices and macroeconomic variables is well illustrated by the theoretical stock valuation models. According to the models, the current prices of an equity share is approximately equal to the present value of all future cash flows, hence any macroeconomic variable that affect cash flow and the required rate of return will in turn influence the share value as well. Stock returns are generally believed to be determined by some fundamental macroeconomic variables.

The volatility of stock returns represents the variability of stock price changes during a particular period of time. Despite being a measure of risk, excessive stock returns volatility or "noise" according to investors undermines the usefulness of the stock prices which is an indicator about the true intrinsic value of the firm (Karolyi, 2001). Growing inflation, fluctuations in exchange rates, broad money supply, and interest rate will increase volatility of stock returns leading to rise in risk and the investors may think of switching their investment to less risky portfolios like bonds.

\subsection{Stock Returns and Macroeconomic Variables}

Evidence from the financial theory suggest that as the global financial markets become more liberalized, there has been a close relationship between stock returns and the macroeconomic variables including interest rates, exchange rate, Gross Domestic Product(GDP), inflation, money supply, etc. These variables have been viewed as the most important determinants of stock market behavior as they are used to describe the state of macro economy that an investor must monitor and forecast in order to make choices regarding their investment decisions (Junkin, 2012).

\subsubsection{Interest Rates}

First, if an investor considers interest rate as cost of capital, an increase or a decrease in interest rate may affect the investment decision of the investors. For example, when there is a rise in interest rate and the opportunity cost goes up, individual investors would prefer to invest in non-fixed income securities such as bonds (Adam \& Tweneboah, 2008). This may result either in profit or loss which is reflected in the firm's balance sheet. When the profit or loss of a firm is immediately announced, the stock price of a firm will increase or decrease. This implies that the valuation of a firm would either increase or decrease its stock price hence stock returns.

Ajayi et al. (1998) observed that when the stock prices decrease, it is expected that the wealth of the domestic investors also go down. Moreover, it may also lead to a lower demand for money hence interest rate decreases. Ceteris paribus, the lower the interest rates the higher the stock prices. Higher stock prices may in turn lead to a surge in capital outflows. This will lead to depreciation of domestic currency. This is a clear indication that there exits interrelationship among stock market, interest rate, and exchange rate. In Kenya, interest rates have been rising and falling depending on the economic situation of the economy. 
The central bank of Kenya through the Monetary Policy committee (MPC) lowered the central bank rate by one hundred basis points to 8.5 percent as at 7 th May 2013 from 9.50 percent on account of sustained inflationary pressures, short term money market rates and stability of the exchange rates (Central Bank of Kenya, 2012). This has an effect on the stock prices and subsequently on the stock returns at the Nairobi Securities Exchange Limited.

\subsubsection{Money Supply}

The effect of money supply on stock prices can either be positive or negative. Since the rate of inflation is positively related to money growth rate, as noted by Fama (1981), an increase in the money supply may lead to an increase in the discount rate and lower stock prices. However, this negative effect may be countered by the economic stimulus provided by money growth, which would likely increase cash flows and stock prices (Mukherjee \& Naka, 1995).

The Central Bank of Kenya has been regulating the amount of money circulating in the economy. This affects the growth of the money hence influencing stock prices and it may have a subsequent on the stock returns in the NSE.

\subsubsection{Gross Domestic Product}

Majority of the studies have found that the current stock levels are positively related to future levels of real economic activity, as measured by Gross Domestic Product (GDP) (Geske \& Roll, 1983; Chen et al., 1986; Sharma, 2002). The levels of Gross Domestic Product (GDP) will likely influence stock returns through its impact on corporate profitability. An increase in output may increase expected future cash and, hence, raise stock prices, while the opposite effect would be valid in a recession.

\subsubsection{Inflation}

A high inflation rate raises the cost of living and results to a shift of resources from investments to consumption. The demand for market instruments falls leading to reduction in the volume of stock traded. This will force the monetary policy authorities to respond to the increased rate of inflation with economic tightening policies, which in turn increases the nominal risk-free rate and hence raises the discount rate in the valuation model (Adam \& Twenoboa, 2008). Nominal contracts that disallow the immediate adjustment of the firm's revenues and costs prevent cash flow to grow at the same rate as inflation (DeFina, 1991).

Kenyan economy has witnessed some significant changes in inflation over time. Consumer Price Index (CPI) increased by 0.95 percent from 137.96 to 139.28 in April 2013 (Republic of Kenya, 2013). There was subsequent effect on stock returns as a result of these changes.

\subsubsection{Exchange Rates}

The currency volatility has effects on the stock returns. When currency appreciates, in a situation where the country is export-oriented, it is expected that there will be a reduction in the competitiveness of her exports, and would therefore have a negative impact on the domestic stock market. This is because the export-oriented companies quoted on the stock exchange market would be less profitable and this may in turn become less attractive to investors (Muthike \& Sakwa, 2012). The opposite happens in a scenario where currency depreciates as exports become competitive. The witnessed fluctuations in Kenya shilling will have an effect on the stock prices depending on whether it appreciates or depreciates. As of May 16th 2013 the Kenya shilling exchange rate remained fairly stable against major international world currencies. The Kenya shilling firmed up against US Dollar to trade at an average rate of Ksh 83.81 (Republic of Kenya, 2013). This change in exchange rates may have a bearing on stock returns in NSE depending on the behavior of currency, whether it appreciates or otherwise.

\subsection{Nairobi Securities Exchange Limited}

Nairobi Securities Exchange (NSE) limited was constituted in 1954 as a voluntary association of stockbrokers registered under the Societies Act (Ngugi, 2005). NSE has been characterized by humble beginnings and it has grown considerably over time. It came into being in the 1920s when Kenya was still a British colony whereby an informal way of dealing in shares and stocks were beginning (Ngugi, 2005). Trading of shares was only limited to members of the European community and Africans but Asians were not permitted to deal in securities until Kenya became independent in 1963 when they were allowed trade in the stock market.

The first privatization in the NSE was through a successful sale of a $20 \%$ government stake in Kenya Commercial Bank in 1988 which saw the Government of Kenya and its affiliate institutions retaining about $80 \%$ of the ownership of the bank (Nairobi Securities Exchange Limited, 2011). It was during the period February 18, 
1994 that NSE 20-share index recorded an all time high of 5030 points. This triggered International Finance Corporation (IFC) rating of NSE as the best performing stock market in the world with a return of $179 \%$ in Dollar terms.

\subsection{The Stock Market Performance in Kenya}

The performance of the NSE to a large extent reflects on policy, institutional framework and the political environment. Stock market in Kenya is influenced by the number of factors the major being the general performance and the nature of the current economic situations in the country. The economic situation is reflected by the changes in the macroeconomic variables such as the level of the Gross Domestic Product, interest rate levels, exchange rate, inflation, the amount of money supply in the economy and other factors beyond the scope of this study such as the employment/ unemployment rate and the activities of the government like general elections.

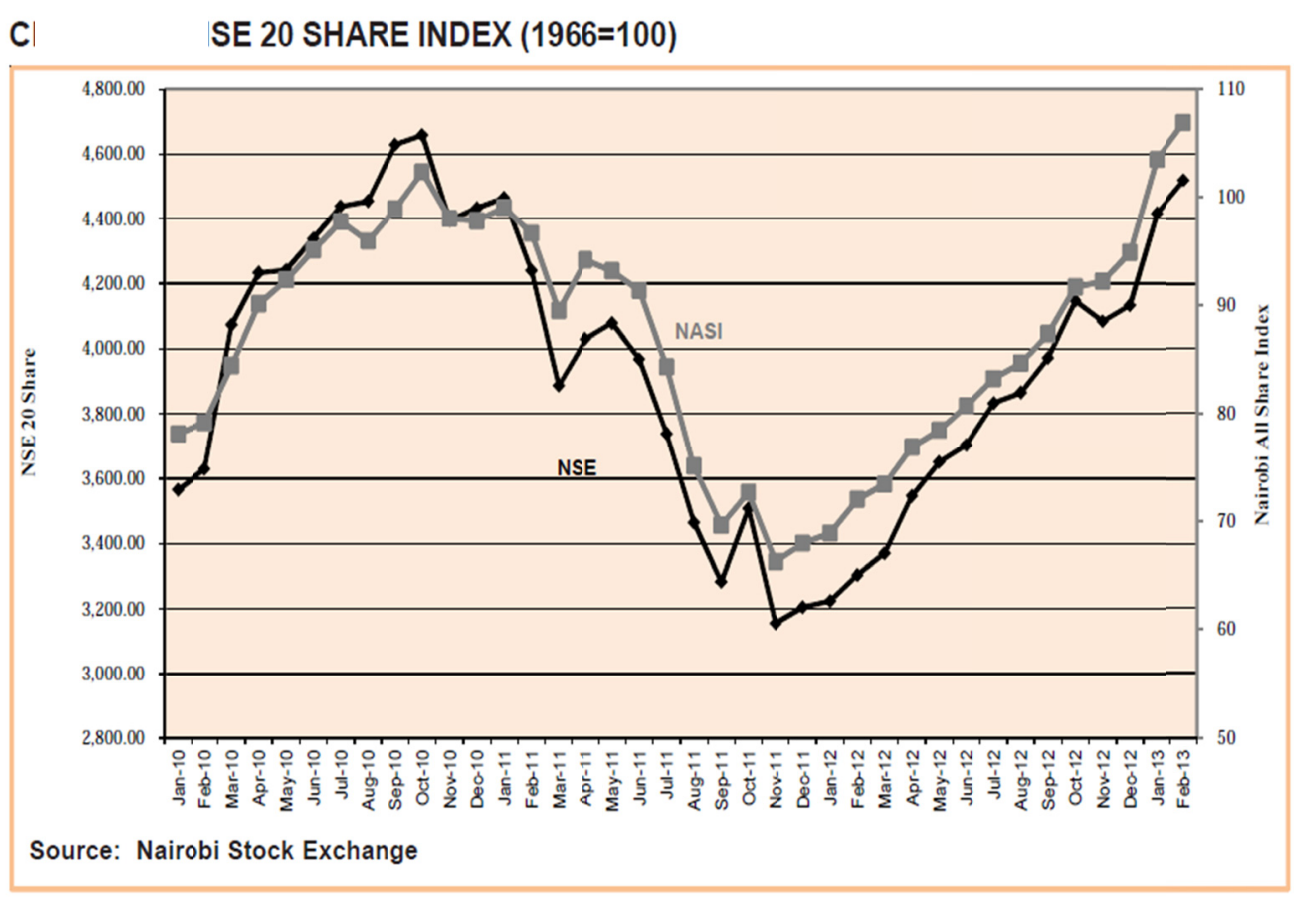

Figure 1. NSE 20 share index from January 2010 to February 2013

From Figure 1, the NSE 20 share index has been fluctuating over time. The performance of the equity market was mixed in October 2010 as reflected by the trend in NSE share index as shown in Figure 1 . The NSE 20 share index rose by 29.8 points ( 0.6 percent) to close at 4659.06 in October 2010 . Increased equity share index was as a result of improved prices in some counters that were active (Central Bank of Kenya, 2010).

Despite increase in number of traded shares on March 2011, the NSE 20 share index lost by 353.1 points (8.3 percent) to close at 3887.1. This was on account of low share prices which can be attributed to depreciation of Kenya shilling against US dollar to a low of KShs 107 per dollar (Central Bank of Kenya, 2011). The overall stock market declined in November 2011 as showed in figure1.1. The NSE share index shed 351.88 points to level at 3155.46 points from 3507.346 points in October 2011 (Central Bank of Kenya, 2011).

By February 2013, NSE share index touched a monthly high since November 2010. The index gained 7.5 percent to reach 4,518.59 points in February 2013 (Central Bank of Kenya, 2013). This implies that the performance of the equity market depends on the nature of the economic environment.

The volatility in NSE share prices are as a result of changes in the economic environment which if not closely monitored may impact negatively on the share returns. Of great concern to share price volatility are fluctuations of the macro variables which have been seen to be the reason behind the assortment of ills that beset the fluctuations in the stock market returns in Nairobi Securities Exchange Limited (Nairobi Securities Exchange, 2013). 


\subsection{Statement of the Problem}

The stock market plays a vital role in economic development of a nation, since it acts as mediator between borrowers and lenders. A well functioning stock market will contribute to development of an economy through two important channels; boosting savings and allowing for more efficient allocation of resources (Junkin, 2012). Furthermore, stock markets allow companies to acquire capital easily and efficiently since they create an enabling environment for business transactions.

However, companies which are quoted on the Nairobi Securities Exchange Limited have been experiencing high stock returns volatility with the highest record of $21.1 \%$ in the history of NSE in 2000 (Kalui, 2004). In 2011, share prices dropped due to adverse economic conditions which were greatly contributed by depreciation of Kenya shillings touching a low of Sh 107 against US dollar (Nairobi Securities Exchange Limited, 2011). The daily upward and downward movement of security prices being witnessed at the Nairobi Securities Exchange has been behind the assortment of ills that has left market turbulent with stock prices dipping low. A highly volatile market will make the investors lose confidence and shy away from trading in that market. This may lead to shut down of the stock market impacting negatively on the economy.

Majority of the studies that have been done to evaluate stock returns, volatility, and the macroeconomic variables mainly emanate from developed markets (Ratanapakorn \& Sharma, 2007; Alshogeathri, 2011). Studies on emerging market especially Kenya is limited. There are limited studies on share returns, volatility, and macroeconomic variables. Evaluating the relationship between macroeconomic variables and stock return is of crucial concern for an economy. Policy makers would wish to establish which variables to control and how in order to create an enabling environment for thriving investments. There is therefore a need for an in-depth and an extensive evaluation of the relationship between stock returns and the macroeconomic variables and the effects of changes in such variables on volatility of the stock returns in the Nairobi Securities Exchange Limited.

\subsection{Research Questions}

This study sought to answer the following questions;

(i) What is the relationship between each of the selected macroeconomic variables and stock returns at the Nairobi Securities Exchange Limited?

(ii) How does NSE share returns respond to shock in each of the macroeconomic variable under study?

(iii) What is the effect of change in each of the macroeconomic variable on stock return volatility in NSE?

\subsection{Objectives of the Study}

The general objective of this study was to analyze the relationship between selected macroeconomic variables, volatility, and stock returns at the Nairobi Securities Exchange Limited.

The specific objectives of this study were to;

(i) Determine the relationship between each of the selected macroeconomic variable and stock market return at the Nairobi Securities Exchange.

(ii) Determine the response of stock market returns to shocks in selected macroeconomic variables.

(iii) Determine the effect of change in selected macroeconomic variables on volatility of stock return in at the Nairobi Securities Exchange.

\subsection{Significance of the Study}

The study offers valuable contribution to theory and practice. This contributes to the limited literature in Kenya stock market by evaluating the relationships between stock market return and selected macroeconomic variables. The study is also essential to the institutions of public and private policies geared towards improving the stability and efficiency of stock markets. This sets the basis under which investors can make informed choices regarding investment decisions.

\subsection{Scope and Organization of the Study}

The study covered the period from the year 2000: Q2 to 2012: Q2 since data was available in those periods. This study is organized as follows; the first chapter gives the introduction. Chapter two reviews the theoretical literature pertaining to stock valuation models and the empirical literature on the relationship between the macroeconomic variables and stock returns. Chapter 3 discusses the methodology, research design, the type of data and data collection methods. Chapter four presents the empirical findings while chapter five presents the summary, conclusion and the policy implications. 


\section{Research Methodology}

\subsection{Introduction}

This chapter sets out the methodology to used to achieve the objectives set out in chapter one. The succeeding section presents the research design used in the study. The third section gives the theoretical framework that was adopted in the study. The fourth section presents empirical model specification. The last two sections highlight the data type, source, and the procedure for analysis.

\subsection{Research Design}

This study investigated the relationship between key macroeconomic variables and Nairobi Securities stock returns and their volatility. Time series research under non-experimental research design was adopted in the study. Regression analysis was used to capture causal relationship between variables, impulse response functions were used to capture the effects of shocks to each of the macroeconomic variable on share returns and volatility models were estimated to capture volatility of stock returns on change in each of the macroeconomic variables.

\subsection{Theoretical Model}

Based on the theoretical and empirical literature reviewed, the methodology adopted by this study was anchored on Market Model. The model provided an important concept that facilitates the analysis of investment portfolios. It explains the realized returns by postulating a linear relationship with realized returns on the market. The model is given as,

$$
R_{j}=\alpha_{j}+\beta_{j} R_{M}+\varepsilon_{j}
$$

Where, $R_{j}, R_{M}$ are the realized returns on share $\mathrm{j}$ and the market respectively. $\alpha_{j}, \beta_{j}$ are constants. $\varepsilon_{j}$ is a random variable uncorrelated with $R_{M}$ and having a distribution with zero expected value. The assumption underlying equation (1) is that all shares are affected to a greater or lesser extent by a common underlying factor, typically developments in the overall market.

In the case of $k$ macroeconomic variables $\left(F_{1}, F_{2}, \ldots, F_{k}\right)$ each security has $k$ sensitivities $\left(\beta_{1}, \beta_{2}, \ldots, \beta_{k}\right)$. The $k$ factor model takes the following form.

$$
R_{i t}=\alpha_{i t}+\beta_{1 t} F_{1 t}+\beta_{2 t} F_{2 t}+\beta_{k t} F_{k t}+\varepsilon_{i t}
$$

Where $R_{i t}$ is return on security $i$ at period.

When returns are generated by multi-factors, equations (1) is obtained. Since this equation is a straight-line, there will be a linear relationship between the expected returns and the sensitivities.

\subsection{Model Specification and the Estimation Procedure}

The relationship between stock returns and the macroeconomic variables at the Nairobi Securities Exchange was implicitly specified as follows,

$$
R=f(G D P, E R, M 2, T B R, I N F)
$$

Where $R$ is the market stock returns and the variables on the right hand side are the real Gross Domestic Product (GDP), real foreign exchange rate (ER), money supply (M2), treasury bill rate (TBR) and inflation (INF).

Equation (3) was explicitly expressed in the form of log linear model as showed in equation (4);

Where, $R_{t}=\operatorname{Ln}\left(P_{t}\right)-\operatorname{Ln}\left(P_{t-1}\right) . P_{t}$ and $P_{t-1}$ are closing values of NSE-20 index for quarter $t$ and $t-1$ respectively.

$$
R_{t}=\beta_{0}+\beta_{1} L n G D P_{t}+\beta_{2} L n E R_{t}+\beta_{3} L n M 2_{t}+\beta_{4} \operatorname{LnTBR}_{t}+\beta_{5} L n I N F_{t}+\varepsilon_{t}
$$

Where $R_{t}=\operatorname{Ln}\left(P_{t}\right)-\operatorname{Ln}\left(P_{t-1}\right) . P_{t}$ and $P_{t-1}$ are closing values of NSE-20 index for quarter $t$ and $t-1$ respectively. $\beta_{0}$ is the intercept, $\beta_{i} s$ are the coefficient of the macroeconomic variables in the model while ' $L n$ ' is the natural logarithm of each variable in the model. After conducting the diagnostic tests equation (4) was estimated.

The effects of change in macroeconomic variables on stock returns volatility was investigated using Threshold Generalized Autoregressive Conditional Heteroscedasticity (TGARCH) model. Symmetric GARCH models would not have been appropriate since it cannot capture leverage effects.

TGARCH model was estimated to capture the impact of news of macroeconomic variables on stock returns volatility. It was developed by Zakoian (1994) and Glosten et al. (1993). It explains the impact of news on volatility. The generalized version is given as: 


$$
\delta_{t}^{2}=\omega+\alpha \delta_{t-1}^{2}+\gamma d_{t-1} \varepsilon_{t-1}^{2}+\beta \varepsilon_{t-1}^{2}
$$

Where $\delta_{\mathrm{t}}^{2}$ is stock return volatility, $\omega$ is a constant and $d_{t-1}$ is a dummy variable such that;

$$
\mathrm{d}_{\mathrm{t}-1}=\left\{\begin{array}{lll}
1, & \text { if } & \varepsilon_{\mathrm{t}-1} \prec 0, \text { bad news } \\
0, & \text { if } \quad \varepsilon_{\mathrm{t}-1} \geq 0, \text { good news }
\end{array}\right.
$$

$\gamma$ (Coefficient of the ARCH term) is the parameter which measure leverage effect or asymmetry. GARCH term coefficient $(\alpha)$ measures the forecast variance from last period. $\alpha+\gamma$ Measures the persistence of shocks to volatility which depends on $\alpha+\gamma$ parameters such that if $\alpha+\gamma<1$ imply a tendency for the volatility response to decay over time, $\alpha+\gamma=1$ imply indefinite volatility persistence to shocks over time, and $\alpha+\gamma>1$ imply increasing volatility persistence over time. The presence of volatility persistence is a sign of market inefficiency. When $\gamma$ is significant and positive, negative shocks have a larger effect on volatility $\left(\delta_{t}^{2}\right)$ than positive shocks (Carter, 2007).

\subsection{Definition, Source, and Measurement of Variables}

The description and measurement of variables is explained in table 3.1 as shown.

\begin{tabular}{|c|c|c|c|}
\hline Type & Variable & Variable Transformation and Measure & Description \\
\hline $\begin{array}{l}\text { Dependent } \\
\text { variable }\end{array}$ & Stock Return & $\begin{array}{l}R_{t}=\operatorname{Ln} P_{t}-\operatorname{Ln} P_{t-1} \\
{[\text { index }]}\end{array}$ & $\begin{array}{l}\text { NSE stock market return. Market } \\
\text { capitalization weighted index of } 20 \\
\text { companies. Measured by quarterly average } \\
\text { of indices. }\end{array}$ \\
\hline \multirow[t]{5}{*}{$\begin{array}{l}\text { Independent } \\
\text { variables }\end{array}$} & Inflation & $\Delta \operatorname{LnCPI} I_{t}=L n C P I_{t}-L n C P I_{t-1}$ & $\begin{array}{l}\text { It is a persistence increase in general prices } \\
\text { of goods and services. Measured by } \\
\text { quarterly percentage change in consumer } \\
\text { price index. }\end{array}$ \\
\hline & Treasury bill Rate & $\operatorname{Ln} T B R_{t}$ & $\begin{array}{l}\text { Treasury bill rate used as a proxy for } \\
\text { domestic rate of interest. It is measured as } \\
\text { the quarterly average of the } 91 \text {-day } \\
\text { Treasury Bill Rate. }\end{array}$ \\
\hline & M2 money supply & $\operatorname{Ln} M_{t}$ [Millions of Kenyan shillings] & $\begin{array}{l}\text { A measure of aggregate money supply that } \\
\text { includes M1 and long-term money } \\
\text { deposits. Measured by quarterly average of } \\
\text { money supply. }\end{array}$ \\
\hline & Exchange rate & $\operatorname{Ln} E R_{t}$ [percentage] & $\begin{array}{l}\text { Measured by quarterly average rate at } \\
\text { which Kenya shillings exchanges with one } \\
\text { US dollar. }\end{array}$ \\
\hline & Gross Domestic Product & $\operatorname{Ln} G D P_{t}[$ Kenya shillings $]$ & $\begin{array}{l}\text { Total market value of final output produced } \\
\text { within the country. Measured quarterly. }\end{array}$ \\
\hline
\end{tabular}

Table 1. Definition and measurements of variables

\subsection{Data Type and Source}

Published time series data was sourced from the Kenya National Bureau of Statistics (KNBS), the Central Bank of Kenya (CBK), the Nairobi Securities Limited (NSE) databases, and the Kenya Statistical Abstracts. The quarterly data of broad money supply (M2), 91-day Treasury bill rate, real exchange rates, were obtained from the Central Bank of Kenya, real GDP, consumer price index (CPI) from the KNBS and NSE 20 share index returns from the NSE Database. The data spans from the second quarter of the year 2000 to the second quarter of the year 2012. The total numbers of observations were 50 .

\subsection{Data Analysis}

Before the model was estimated, diagnostic tests was carried out. Non-stationary time series data has often been a problem in empirical analysis as it may yield spurious regressions. To eliminate this problem, stationarity of the variables under study was tested. In testing for stationary, the standard Augmented Dickey-Fuller test was performed to test for the existence of the unit root (Dickey, 1979; Fuller, 1979). Non-constant variance in time series data poses a problem in their analysis. Hence Bruesch-Pegan-Godfrey test was used to test for heteroskedasticity in the stochastic term. Adjusted $\mathrm{R}^{2}$ and $\mathrm{F}$ statistics were utilized to evaluate parsimony, 
stability and reliability of each model (Wooldridge, 2003).

The first objective was achieved by establishing the statistical significance of the individual coefficient using two-tailed tests since they assumed negative or positive values. This was done by running Ordinary Least Squares on the multiple regression equation (4).

Long-run relationship was established by using Engle-Granger two-step method which is residual based approach was used to test for cointegration among the variables. After establishing the existence of cointegration among the variables, an Error Correction Model was estimated to test for the short and long-run dynamics. An error correction model was formulated by regressing the first differences of the dependent variable on to the values of the first difference of the explanatory variables plus the lagged value of the ECM as shown in equation (6).

$$
R_{t}=\beta_{0}+\beta_{1} \Delta L n G D P_{t}+\beta_{2} \Delta L n E R_{t}+\beta_{3} \Delta L n T B R_{t}+\beta_{4} \Delta L n I N F_{t}+\lambda E c m_{t-1}+\varepsilon_{t}
$$

Objective number two was achieved by carrying out impulse response analysis. The responsiveness of stock market returns was traced out by a one standard deviation shock in each of the macroeconomic variable. The sign, magnitude, and the persistence of the responses of stock market return were taken into consideration.

Objective three was achieved by estimating Threshold Generalized Autoregressive Conditional Heteroscedasticity (TGARCH) model equation (5). The T-GARCH model captures the impact of news about changes in macroeconomic variables. It tests the presence of the leverage effects and the persistence of volatility returns at the stock market.

\section{Empirical Findings}

\subsection{Introduction}

This chapter presents empirical results including descriptive statistics, unit root tests, co integration, error correction regression models, relevant econometric tests, and key findings from the investigations.

\subsection{Descriptive Statistics for Variables}

Sample mean, standard deviation, skewness and kurtosis, and the Jacque-Bera statistics and the p-value have been reported. The high standard deviation of the stock returns (RT) with respect to mean implies that there is high volatility at the stock market.

The Jarque-Bera (JB) test statistic was used to determine whether or not macro-economic variables and the NSE stock returns follow the normal probability distribution. The JB test of normality is a large-sample or asymptotic test that computes kurtosis and the skewness measures and uses the following test statistic:

$$
J B=n\left[\frac{s}{3}+\left(\frac{k-3}{12}\right)\right]
$$

Where $\mathrm{n}=$ sample size, $\mathrm{S}=$ skewness coefficient, and $\mathrm{K}=$ kurtosis coefficient. For a normally distributed variable, $\mathrm{S}=0$ and $\mathrm{K}=3$. Therefore, the JB test of normality is a test of the joint hypothesis that $\mathrm{S}$ and $\mathrm{K}$ are 0 and 3 respectively.

All the variables are not normally distributed apart from stock returns (RT) whose skewness coefficient is close to zero $(-0.257588)$ and kurtosis coefficient of 3.075905. The non-normally distributed variables were converted into logarithms for them to be normally distributed.

\subsubsection{Correlation Analysis Results}

The Logic behind the assumption of no multicollinearity is that if two or more independent variables are correlated with each other, one of them should be dropped from the list of variables. In order to check multicollinearity among independent variables, a correlation analysis was performed. A suggested rule of the thumb was that if the pair wise correlation between two regressors is very high, in excess of 0.8 , multicollinearity may pose serious problem (Adam \& Twenoboah, 2008). The worst consequence of multicollinearity is that it increases the variances and standard errors of the OLS estimates. High variances mean that the estimates are imprecise, and therefore not very reliable. High variances and standard errors imply low t-statistics (Granger, 2001).

All the correlation values are lower than 0.8 except for M2 and GDP in which the correlation is 0.937069 . Broad money supply M2 was dropped a since it affected the co itegration test. The test showed no co integration among the variables when M2 is included in the model, whereas the cointegration test in the presence of GDP was found. 


\subsection{Stationarity Analysis}

An important concern in data analysis is to determine whether a series is stationary (do not contain a unit root) or not stationary (contains a unit root). Time series data are often assumed to be non-stationary and thus it was necessary to perform a pretest to ensure that all the variables were stationary in order to avoid the problem of spurious regression (Granger, 2001).

The results showed that for stock returns (RT) the null hypothesis of non stationary was rejected implying that it was stationary at level. Evaluation of the results was guided by the critical values provided by Mackinnon (1996). This implied that stock returns (RT) is integrated of order zero I (0). Other macroeconomic variables; Gross Domestic Product, Treasury Bill Rate, Inflation, and Exchange Rate were found to be non-stationary at level. However they became stationary after the first difference. This means that they are integrated of order one, I (1).

\subsection{Co Integration Test Results}

Co integration was done so as to test for the presence of long run relation among two or more variables. Regression model of stock returns against Treasury bill rate, exchange rate, inflation and Gross Domestic product was done to get the fitted residual which was then subjected to unit root test to confirm or not the existence of co integration among the variables. The test statistics of the residuals obtained were compared to the critical values for co integration test for Engle-Granger approach provided by Davidson and MacKinnon (1993).

The results show that the residuals are stationary hence there is co integration implying existence of a long-run relationship in the variables. According to Brooks (2008), if variables with differing orders of integration are combined, their combination will have an order of integration equal to the largest. Since unit root test results indicated that all the variables were integrated of order one, I(1) except for the stock returns which was integrated of order zero, $\mathrm{I}(0)$, the order of integration was taken to be one, I(1). Engel and Granger (1987) observed that the cointegrated variables must have an Error correction model (ECM) representation. An ECM was therefore constructed (as shown in equation 3.6 in chapter three) and estimated to establish the Short-run relationships among the variables. Formulating an ECM involves regressing the first differences of the dependent variable on to the values of the first difference of the explanatory variables plus the lagged value of the ECM.

The ECM relates the short run changes in the dependent variables to the short run changes in the explanatory variables. It links it with the changes to the long-run effect through the feedback mechanism (Wooldridge, 2003). It also measures the speed at which the dependent variable adjusts to the changes in the explanatory variables before converging to equilibrium.

\subsection{Diagnostic Tests Results}

The regression model of differenced value of the stock returns (dependent variable) against differenced values of Log of Treasury bill rate, Log of Inflation, Log of Gross Domestic Product, Log of Exchange Rate and the error correction term was estimated. Diagnostic tests for the estimated model were done and the results are hereby discussed.

Ramsey test was used to test for the correct model specification. In this test, if non-linear combinations of the explanatory variables do not have any power in explaining the endogenous variable, the model is correctly specified (Ramsey, 1969). The null hypothesis of the test is that the model is linear against an alternative. The results show that the null hypothesis of non-linearity was rejected since its p-value is less than $5 \%$. The model was therefore correctly specified

Serial correlation is a statistical term used to describe the situation when the residual is correlated with lagged values of itself which is not desirable .Breusch-Godfrey Serial Correlation LM Test was used to test for the presence of serial correlation on the residuals. The null hypothesis is of no serial correlation. The p-value is 0.537446 (53\%) which is more than 5 percent ( $>0.05$ ), hence null hypothesis could not be rejected. This means that residuals $(\mathrm{u})$ are not serially correlated which is desirable.

Heteroscedasticity is a term used to describe the situation when the variance of the residuals from a model is not constant. Breusch-Pegan-Godfrey test (B-P-G Test) was used to test for the presence of heteroscedasticity. The p-value is $0.450495(45 \%)$ which shows that null hypothesis of homoscedasticity cannot be rejected. This implies that the residuals have constant variance which is desirable.

One of the assumptions of the regression model is that the error term, follows the normal distribution. Jarque Berra statistics was used to test for normality. The result in show that its value is 1.3981 and the corresponding $p$ value is 0.4970 . Since $p$ value is greater than 5 percent the null hypothesis of normal distribution cannot be 
rejected meaning that population residual is normally distributed which fulfills the assumption of a good regression line.

\subsection{The Relationship between Macroeconomic Variables and Stock Returns}

The relationship between the stock returns and the macroeconomic variables was established by estimating a regression equation. It involved regressing differenced value of stock returns on the first difference values of log of Gross Domestic Product, log of exchange rate, $\log$ of inflation and $\log$ of Treasury bill rate. The results of the estimation are reported in Table 2.

Table 2. Results of the regression model

\begin{tabular}{llll}
\hline $\begin{array}{l}\text { Variable } \\
\text { [Dependent Variable: Differenced Log value } \\
\text { of stock returns] }\end{array}$ & Coefficient Estimates & t-statistics & P-values \\
\hline Differenced Log of Treasury bill rate & -0.053 & -1.620 & 0.112 \\
Differenced Log of Inflation & 0.038 & 1.297 & 0.201 \\
Differenced Log of Gross Domestic Product & 0.385 & 1.622 & 0.112 \\
Differenced Log of Exchange Rate & -1.403 & -4.404 & 0.000 \\
Error Correction Term & -0.771 & -4.939 & 0.000 \\
Constant & 0.003 & 0.221 & 0.826 \\
Adj. $R^{2}=0.470(53 \%)$, Prob (F-statistic) $=0.000$, Durbin Watson $=1.932$ & & \\
\hline
\end{tabular}

From Table 2, Adjusted $\mathrm{R}^{2}$ is $47 \%$. This shows that $47 \%$ of the variations in the value of stock returns are explained by Exchange rates, Inflation, GDP and Treasury bill rate. The F-statistic is significant at all levels implying that the hypothesized relationship between the stock returns and the selected macroeconomic variables is validated. The value of Durbin-Watson statistic is 1.9 implying that then model is not suffering from autocorrelation problem.

The regression results in Table 2 show that the first difference value of stock returns is affected by the first difference value of log of exchange. This finding is similar to the results of the study by Adam and Tweneboah (2008) and that of Olweny and Omondi (2011). For a one percentage increase in depreciation of a domestic currency, the model predicts stock returns to decrease by 1.4 percent. The findings of the study by Ahmet (2010) show that stock returns deceases by 1.033 percent for a one percent decrease in the value of Turkish domestic currency. The effect of change in the exchange rate on stock returns was higher at the Nairobi Securities Exchange Limited compared to the Turkish Stock Exchange. This implies that the NSE was too sensitive to the changes in macroeconomic variables than the Turkish economy.

From the results of the multiple regression model, first difference values of log of inflation rate, log of Gross Domestic Product, log of Treasury bill rate show no effect on the first difference values of stock returns. This was similar to the findings of the study by salameh (1997) which documented that there is no relationship at all between stock returns and inflation. Another study by Suliaman (2009) indicated that the Industrial Production (a proxy for GDP) did not affect stock returns. The insignificant effect of these variables on stock returns may have been attributed to the influence of other internal and external macroeconomic factors (budget deficits, balance of trade, changes in oil prices) on the stock market return which was not investigated in this study.

The coefficient of the error correction term in the model is negative and statistically significant. The estimated coefficient value of -0.77 of the error correction mechanism implies that the system corrects its previous period's disequilibrium from the long-run estimates by $77 \%$ quarterly. The high significance of the coefficient of ECM term supports the existence of a long-run equilibrium relationship between stock returns and the macroeconomic variables which influences it.

\subsection{The Response of Stock Market Returns to Shocks in Each Macroeconomic Variable}

To examine the signs and persistence of the short-run response of the stock market returns to one standard error shocks in each of the macroeconomic variables, impulse response functions were estimated. Impulse response function for exchange rate only was done since other macroeconomic variables; Gross Domestic Product, Inflation and the Treasury bill rates were not important in determining stock market returns. Figure 4.1 shows the results of the response of stock market returns resulting from one standard deviation shock in exchange rate. 
Response of DRT to DLER

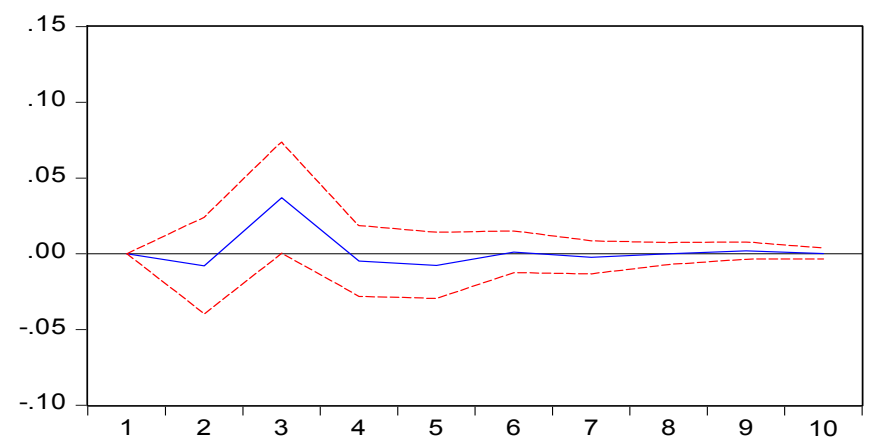

Figure 2. Impulse Response Function of stock returns to shock in exchange rate

The effects of shock in exchange rate declines in the mid second quarter but rises in third quarter. It declines in the fourth quarter and reverts to equilibrium in the subsequent quarters. The decline in stock returns as a result of the shock is consistent with the findings from the regression model that stock returns were negatively related with exchange rate. Similar findings were reported in the study by Adam and Twenoboah (2008).

\subsection{Effect of Changes in Macroeconomic Variables on Volatility of Stock Return}

The effect of changes in macroeconomic variables on the volatility of stock returns was analyzed by estimating TGARCH model. As presented in the chapter three, the coefficient of the ARCH term given by $\gamma$ measures the presence of leverage effects. If the coefficient of leverage effect $(\gamma)$ is positive and significant, then there is presence of leverage effects which implies that periods of low volatility tends to be followed by another period of low volatility for a prolonged period of time and vice versa. The preliminary test portrays stock returns to be exhibiting leverage effects. An ARCH test was then done for each macroeconomic variable to test for the presence of ARCH effect so as to allow for an estimation of a TGARCH model. The results showed absence of ARCH effects on inflation hence TGARCH model could not be estimated. The results of the model were evaluated at $1 \%, 5 \%$ and $10 \%$ levels of significance.

\subsubsection{Effect of Change in Treasury Bill Rates on Volatility of Returns from Stocks}

TGARCH model was estimated to find out the effect of change in Treasury bill rate on stock return volatility. The null hypothesis of no ARCH effect was rejected and it provided evidence of the presence of ARCH effects. The evidence of ARCH which is another evidence of presence of leverage effects paved way for the estimation of the TGARCH model. The results are presented in Table 3.

Table 3. TGARCH results for treasury bill rate and the stock returns

\begin{tabular}{lccc}
\hline Name of the coefficient & Value of Coefficient & z-statistics & Probability value \\
\hline Constant $[\omega]$ & 0.004 & 1.426 & 0.1540 \\
GARCH Term $[\alpha]$ & -0.048 & 0.118 & 0.6817 \\
Coefficient for Leverage effect or ARCH term $[\gamma]$ & 1.022 & 2.097 & 0.0360 \\
\hline
\end{tabular}

The findings as shown in Table 3 provide evidence that news impact is asymmetric since $\gamma \neq 0$. The coefficient of leverage effect $\gamma$ is significant and positive meaning that negative shocks have a larger effect on volatility $\left(\delta_{t}^{2}\right)$ than positive shocks. This is similar to the results of study by Carter (2007). This is an indication that bad news increases volatility in the market implying that there is existence of leverage effect. The significance is also further evidence that bad news has a significant impact on stock return volatility than good news. Volatility persistence was absent since $\alpha+\gamma$ is insignificant. The results are similar to those in the study by Olweny and Omondi (2011).

\subsubsection{Effect of change in the Exchange Rate on Volatility of Returns from Stocks}

Before the model was estimated, the residuals were examined for heteroscedasticity where the ARCH-LM test provided strong evidence of ARCH effects in the residual series. The null hypothesis of no ARCH effect is rejected and concludes that there is presence of ARCH effects. The presence of ARCH effects paved way for the estimation of the TGARCH model. The results of the TGARCH model are reported in Table 4. 
Table 4. TGARCH results for exchange rate and the stock returns

\begin{tabular}{lccc}
\hline Name of the coefficient & Value of Coefficient & z-statistics & Probability value \\
\hline Constant $[\omega]$ & 0.004 & 1.184 & 0.237 \\
GARCH Term $[\alpha]$ & -0.054 & -0.325 & 0.745 \\
Coefficient for Leverage effect or ARCH Term $[\gamma]$ & 0.944 & 1.784 & 0.074 \\
\hline
\end{tabular}

Exchange rate as shown from the results in Table $4 \gamma$ is significant and positive which proves the presence of leverage effect. The significance of this coefficient indicates that negative shocks (bad news) have a larger effect on the conditional variance (volatility) than positive shocks (good news) of the same magnitude. The results are similar to that of the study by Olweny and Omondi (2011) and Suliman and Winker (2012). There was absence of volatility persistence as the value of $\alpha+\gamma$ was not important.

\subsubsection{Effect of Change in GDP on Volatility of Returns from Stocks}

The residuals were also tested for the presence of ARCH effects before estimating TGARCH model to examine the effects of GDP fluctuations on stock returns volatility at the NSE. The residual test provided evidence of the presence of ARCH effects in the residual series. The null hypothesis of no ARCH effect is rejected and concludes that there is presence of ARCH effects. The presence of ARCH effects paved way for the estimation of the TGARCH model. The results are reported in Table 5.

Table 5. TGARCH results for GDP and the stock returns

\begin{tabular}{lccc}
\hline Name of the coefficient & Value of Coefficient & Probability value & z-statistics \\
\hline Constant $[\omega]$ & 0.004 & 0.146 & 1.453 \\
GARCH Term $[\alpha]$ & -0.054 & 0.691 & -0.398 \\
Coefficient for Leverage effect or ARCH Term $[\gamma]$ & 0.990 & 0.043 & 2.023 \\
\hline
\end{tabular}

The effect $\gamma \neq 0$ and its significance at $5 \%$ and $10 \%$ levels of testing suggest the presence of leverage effects in the returns series and that bad news has a larger impact on stock return volatility. Also, being significant implies that these effects are more pronounced during the sample periods. Volatility persistence is not reported since its coefficient is insignificant. These results are found to be similar to those of the study by Adjasi et al. (2008).

\section{Summary, Conclusion and Policy Implications}

\subsection{Summary}

Quoted companies at the Nairobi Securities Exchange Limited have been experiencing high stock returns volatility. Fluctuations of macroeconomic variables have been labeled as the reasons behind the daily upward and downward movement of security prices being witnessed at the Nairobi Securities Exchange. This has left market turbulent with stock prices dipping low.

This study examined the relationships between the NSE stock returns and a set of macroeconomic variables during the period of January 2000 to June 2012. The time series data set employed in this study comprised the quarterly observations of the Nairobi Securities Exchange Limited (NSE), the inflation rate (CPI), Treasury Bill Rate (TBR), Exchange rate (ER), and the Gross Domestic product (GDP). Engle-Granger two-step method test was used to examine the existence long run relationship among the variables. Linear error correction model was used to investigate the speed of adjustment of the co integrating variables. The effect of the one standard deviation shock was traced by impulse response functions. Volatility of stock returns in response to changes in macroeconomic variables was traced by the TGARCH model which was estimated in this study.

From the study findings, it was established that only exchange rate had an effect on stock returns. There was a negative relationship between stock returns and the exchange rate. The effects of one standard deviation shock in exchange rate resulted in the declined of stock returns in the mid of the second quarter but rose in third quarter. It declined in the fourth quarter and reverted back to the equilibrium in the subsequent periods. The decline in stock returns supported the negative and significant coefficient of the exchange rate.

The empirical evidence on the effect of fluctuations in macroeconomic variables under study on stock return volatility was that news impact was asymmetric. This was indicated by the leverage effect coefficient, $\gamma \neq 0$, which was significant and positive. It implied that negative shocks had larger effect on volatility than positive shocks. 


\subsection{Conclusion}

Empirical evidence from the study showed a negative relationship between stock returns and the exchange rate. The conclusion is that exchange rate affects stock returns. Other macroeconomic variables were not important in explaining stock returns. One standard deviation shock to the first differenced value of log of exchange rate negatively affects stock returns. This is evidence that stock returns were negatively related to changes in exchange rates.

The effect of changes in macroeconomic variables on volatility of stock returns revealed that the impact of news is asymmetric and that there were leverage effects. This was concluded that negative shocks (bad news) or negative news about changes in macroeconomic variables under study had a larger effect on the conditional variance (volatility) of stock returns than positive shocks (good news) of the same magnitude.

\subsection{Policy Implications}

The following policy implications arise from the study findings:

The government should put in place appropriate policy measures to ensure that the exchange rate is stabilized. This is because empirical evidence from study has shown that exchange rate affects stock returns. Depreciation in the exchange rate leads to a decline in returns from the Nairobi Securities exchange. Once the currency is stabilized, it will create the investors' confidence in the Nairobi Securities Exchange Limited. As a result, it will have a significant impact on the performance of the Kenyan stock market and hence fosters economic growth.

The government of Kenya should put in place measures that will curtail depreciation of the Kenya currency .The results of the study findings have showed that a shock to exchange rates showed negative response to stock returns. This implies that exchange rate and stock returns are negatively related.

The government should seek to minimize fluctuations on the variables; exchange rate, GDP Growth, and the interest rates through the Treasury bill rates. This is because empirical findings revealed that NSE is volatile which is as a result of fluctuations in macroeconomic variables. Those variables that resulted in stock return volatility were exchange rate, Treasury bill rate and GDP. Absence or minimal fluctuation in these variables may not impact negatively on the Nairobi Securities exchange performance.

\subsection{Areas for Further Research}

Future studies may be conducted to identify other macro-economic variables which were not captured in this study that significantly affect stock returns. It is therefore suggested that a wide range of factors may be relevant in determining the stock market returns. Such variables may include but not limited to political uncertainties, unemployment/employment levels, export earnings, regional stock market indices, broadband internet penetration, regional retail sales, and bankruptcies among others.

Further studies on persistence of news on stock return will be useful to investors in making rational investment decisions and aid the regulator in policy formulation. This will be enhanced by the use of other volatility models like PGARCH in not only determining the impact of news on stock returns, but narrow it down to good news and bad news and the persistence of the news on stock return volatility.

\section{References}

Adam, A. M., \& Tweneboah, G. (2008). Do Macroeconomic Variables Play any Role in the Stock Market Movement in Ghana? MPRA Working Paper No. 9368.

Adjasi, C. (2008). Macroeconomic volatility and stock price volatility in small stock markets: Evidence from Ghana. African Journal of Accounting, Economics, Finance and Banking Research, 3(3), 28-47.

Alile, H. (1997). Government Must Divest. The Business Concord of Nigeria 2nd December.

Ashaolu, T. O., \& Ogunmuyiwa, M. S. (2011). An Econometric Analysis of the Impact of Macro Economic Variables on Stock market movement in Nigeria. Journal of Business Management, 3(1), 72-78.

Alshogeathri, M. A. M. (2011). Macroeconomic determinants of the stock market movements: empirical evidence from the Saudi Stock market. Retrieved from http://krex.k-state.edu/dspace/handle/2097/11989

Ahmed, S. (2008). Aggregate economic variables and stock markets in India. International Research Journal of Finance and Economics, 14, 141-164.

Ajayi, R., Friedman, J., \& Mehdian, S. (1998). On the relationship between stock returns and exchange rates: test for granger causality. Global Finance Journal, 9(2), 241-251. http://dx.doi.org/10.1016/S1044-0283(98)90006-0 
Canova, F., \& De Nicolo, G. (1995). Stock returns and real activity: a structural approach. European Economic Review, 39(5), 981-1015. http://dx.doi.org/10.1016/0014-2921(95)00017-8

Caporale, T., \& Jung, C. (1997). Inflation and real stock prices. Applied Financial Economics, 7(3), 265-266. http://dx.doi.org/10.1080/096031097333619

Carter, R. H., William, E., \& Li, M. C. (2007). Principles of Econometrics (3rd ed.). New York: John Wiley and Sons. Inco.

Central Bank of Kenya. (2013). Monthly Economic Review. Retrieved from http://www.centralbank.go.ke

Chinzara, Z. (2011). Macroeconomic Uncertainty and Conditional Stock Market Volatility in South Africa. South African Journal of Economics, 79, 27-49. http://dx.doi.org/10.1111/j.1813-6982.2011.01262.x

Cousina, J. G., \& De Launoisb, T. (2007). News Intensity and Conditional Volatility on the US stock market. AFFI. Retrieved from http:\ffbc.univlille2.fr/fileadmin/user_upload/Espace_enseignants/Cousin_Jean-Gabriel/papier/C072.pdf

DeFina, R. H. (1991). Does Inflation Depress the Stock Market? Business Review, 3-12.

Elly, O. D., \& Oriwo, A. E. (2013). The Relationship Between Macro Economic Variables And Stock Market Performance In Kenya. DBA Africa Management Review, 3(1). Retrieved from http:॥www.uonbi.ac.ke/journals/files/journals/3/articles/1090/submission/review/1090-3950-1-RV.pdf

Emenike, K. O. (2010). Modelling Stock Returns Volatility in Nigeria Using GARCH Models. MPRA Paper No. 23432, posted 05. August 2013.

Erdem, C., Arslan, C. K., \& Sema Erdem, M. (2005). Effects of macroeconomic variables on Istanbul stock exchange indexes. Applied Financial Economics, 15(14), 987-994. http://dx.doi.org/10.1080/09603100500120365

Granger, C. W. J. (2001). Essays in econometrics: collected papers of Clive W. J. Granger (Vol. 1). Cambridge University Press. Retrieved from http://books.google.com/books

Humpe, A., \& Macmillan, P. (2009). Can Macroeconomic Variables Explain Long-Term Stock Market Movements? A Comparison of the US and Japan. Applied Financial Economics, 19, 111-119. http://dx.doi.org/10.1080/09603100701748956

Junkin, K. (2012). Macroeconomic determinants of stock market behaviour in South Africa. Rhodes University. Retrieved from http://eprints.ru.ac.za/3658/

Kalui, F. M. (2004). Determinants of stock price volatility. An empirical investigation of NSE Unpublished MBA research project, University of Nairobi.

Kandir, S. Y. (2008). Macroeconomic Variables, Firm Characteristics and Stock Returns: Evidence from Turkey. International Research Journal of Finance and Economics, 16. Retrieved from http://www.eurojournals.com/Pages\%20from\%20irjfe16serkan.pdf

Karamustafa, O., \& Kucukkale, Y. (2003). Long Run Relationships between Stock Market Returns and Macroeconomic Performance: Evidence from Turkey. EconWorking Papers. Retrieved from http://128.118.178.162/eps/fin/papers/0309/0309010.pdf

Karolyi, G. A. (2001). Why stock return volatility really matters. Strategic Investor Relations. Retrieved from http://bryongaskin.net/education/MBA\%20track/Current/Mba611/Assignments/Project/WhyVolatilityMatte rs.pdf

Kiptoo, C. S. (2010). An empirical investigation of the relationship between selected macroeconomic variables and stock prices: Evidence from the NSE. Unpublished MBA research project, University of Nairobi.

Kithinji, A., \& Ngugi, W. (2005). Stock market performance before and after general elections-a case study of thenairobi stock exchange. Retrieved from http://www.aibuma.org/archive/proceedings/downloads/Angela\%20Kithinji,\%20Kenya.pdf

Maghyereh, A. (2002). Causal relations among stock prices and macroeconomic variables in the small, open economy of Jordan. Open Economy of Jordan. Retrieved from http://papers.ssrn.com/sol3/papers.cfm?abstract_id=317539

Modigliani, F., \& Miller, M. H. (1958). The cost of capital, corporation finance and the theory of investment. The American Economic Review, 48(3), 261-297. 
Moolman, E., \& Du Toit, C. B. (2005). An econometric model of the South African stock market. Retrieved from http://repository.up.ac.za/handle/2263/3031

Muradoglu, G., Metin, K., \& Argac, R. (2001). Is There a Long-Run Relationship between Stock Returns and Monetary Variables: Evidence from an Emerging Market. Applied Financial Economics, 11, 641-649. http://dx.doi.org/10.1080/09603100110094411

Mutai, N. (2005). Macroeconomic factors affecting stock prices at the Nairobi Stock Exchange. Master of Arts Kenyatta University Unpublished Research Project.

Muthike, S. W., \& Sakwa, M. M. (2012). Can macroeconomic indicators be used as predictors of the stock exchange index trends? A look at the Nairobi stock exchange. In Scientific Conference Proceedings. Retrieved from http://elearning.jkuat.ac.ke/journals/ojs/index.php/jscp/article/view/731

Suliman, Z., \& Winker, P. (2012). Modelling Stock Market Volatility Using Univariate GARCH Models:Evidence from Sudan and Egypt. International Journal of Economics and Finance, 4(8).

Sharma, S. C., \& Wongbangpo, P. (2002). Long-term trends and cycles in Asean stock markets. Review of Financial Economics, 11(4), 299-315. http://dx.doi.org/10.1016/S1058-3300(02)00062-9

Sharpe, W. F. (1964). Capital Asset Prices: A Theory of Market Equilibrium under Conditions of Risk. The Journal of Finance, 19(3), 425-442.

Ochieng, \& Odhiambo. (2012). The relationship between macroeconomic variables and stock market performance. University of Nairobi Unpublished paper.

Ogum, G., Beer, F., \& Nouyrigat, G. (2005). Emerging Equity Market Volatility: An Empirical Investigation of Markets in Kenya and Nigeria. Journal of African Business, 6(1), 139-154. http://dx.doi.org/10.1300/J156v06n01_08

Olweny, T. O., \& Kimani. (2011). Stock market performance and economic growth. Empirical Evidence from Kenya using Causality Test Approach. Retrieved from http://www.scienpress.com/Upload/AMAE/Vol\%201_3_9.pdf

Whitelaw, R. (2000). Stock Market Risk and Return: An Empirical Approach. Review of Financial Studies, 13(3), 521-547. http://dx.doi.org/10.1093/rfs/13.3.521

Zakoian, J. M. (1994). Threshold heteroskedastic models. Journal of Economic Dynamics and Control, 18(5), 931-955. http://dx.doi.org/10.1016/0165-1889(94)90039-6

\section{Copyrights}

Copyright for this article is retained by the author(s), with first publication rights granted to the journal.

This is an open-access article distributed under the terms and conditions of the Creative Commons Attribution license (http://creativecommons.org/licenses/by/3.0/). 